\title{
Aquatic vegetation as an indicator of littoral habitats and various stages of lake aging in north-eastern Poland
}

\author{
Stanisław Kłosowski*, Ewa Jabłońska and Marcin Szańkowski \\ Department of Plant Ecology and Environmental Conservation, University of Warsaw, Al. Ujazdowskie 4, 00-478, Warsaw, Poland
}

Received 20 September 2010; Accepted 28 February 2011

\begin{abstract}
The habitats of 356 phytocoenoses dominated by 15 species of aquatic plants were investigated. Among the properties of water, $\mathrm{Na}^{+}, \mathrm{pH}$, total $\mathrm{Fe}, \mathrm{Ca}^{2+}, \mathrm{NO}_{3}{ }^{-}, \mathrm{SO}_{4}{ }^{2-}$, hardness and $\mathrm{COD}-\mathrm{KMnO}_{4}$ were the most important in differentiating the habitats of the phytocoenoses studied. Considerable physicochemical differences were found between the waters of the phytocoenoses of Ranunculus circinatus (hard waters rich in $\mathrm{Na}^{+}$), Nuphar pumila (soft waters with high levels of total $\mathrm{Fe}$ ), Elodea canadensis, Ceratophyllum demersum (alkaline waters) and Stratiotes aloides (waters containing high concentrations of $\mathrm{Ca}^{2+}$ and $\mathrm{SO}_{4}{ }^{2-}$ ). The substrate properties that best differentiated the habitats compared were $\mathrm{PO}_{4}{ }^{3-}$, hydration, organic matter content, total $\mathrm{N}$, dissolved $\mathrm{SiO}_{2}, \mathrm{Ca}^{2+}, \mathrm{Na}^{+}$and $\mathrm{pH}$. Patches of $R$. circinatus inhabited substrates containing the highest levels of $\mathrm{PO}_{4}{ }^{3-}$. Those of $S$. aloides were associated with substrates poor in $\mathrm{PO}_{4}{ }^{3-}$. Patches of $C$. demersum were confined to substrates rich in total N. Phytocoenoses of $R$. circinatus were associated with large lakes, whereas those of $N$. pumila were restricted mostly to smaller lakes. The deepest parts of lakes were inhabited by Potamogeton lucens. Phytocoenoses of $S$. aloides occurred mostly in shallow waters, on thick sediments. The investigated phytocoenoses also represent different stages of succession. The phytocoenoses of Potamogeton perfoliatus, R. circinatus, Myriophyllum spicatum and Polygonum amphibium, which develop on mineral substrates, initiate the process of succession, whereas those of Myriophyllum verticillatum, Nymphaea candida, Nymphaea alba, N. pumila and S. aloides, which inhabit highly hydrated organic substrates, are characteristic of the late stages of succession.
\end{abstract}

Key words: Submerged and floating-leaved phytocoenoses / habitat indicators / water and substrate analyses / process of succession / Water Framework Directive

\section{Introduction}

Aquatic plants and their communities are an important component of water ecosystems. They often occupy a large part of the littoral zone and as such constitute a land-water ecotone (e.g., Melzer, 1999; Lorens et al., 2003). The allochthonous material derived from elsewhere that enters a body of water passes through the land-water interface and often undergoes changes (e.g., Misztal et al., 2003). The aquatic vegetation also plays an important role in a number of natural and anthropogenic processes that occur within a body of water, such as circulation of nutrients (e.g., Carpenter and Lodge, 1986), eutrophication (e.g., Lind and Cottam, 1969; Blindow, 1992; Sand-Jensen et al., 2000; Egerston et al., 2004; Mäemets et al., 2010), acidification (Roelofs, 1983; Arts et al., 1990; Arts, 2002) and aging of bodies of water (e.g., Barko et al., 1991; Marek, 1992; Van Groenendael et al., 1996). Consequently, studies of

\footnotetext{
*Corresponding author: s.klosowski@uw.edu.pl
}

the relationships between macrophytes, the communities they form and their habitats have been conducted worldwide for many years (e.g., Pietsch, 1972; Wiegleb, 1978; Papastergiadou and Babalonas, 1993a, 1993b; Toivonen and Huttunen, 1995; Nurminen, 2003; Lacoul and Freedman, 2006; Lumbreras et al., 2008; Lukács et al., 2009). These studies have been aimed at understanding the role that macrophytes play as indicators of change taking place in water ecosystems.

In connection with the formulation and implementation of the EU Water Framework Directive (European Commission, 2000), in recent years attempts have been made to develop standardized methods of assessing the ecological status of rivers and lakes based on aquatic plant and vegetation sampling (e.g., Schamburg et al., 2004; Schneider, 2007; Penning et al., 2008a, 2008b; Tóth et al., 2008; McElarney and Rippey, 2009).

In Poland, studies on the ecology of aquatic vegetation have been conducted for several decades (e.g., Kłosowski, 1985, 1990; Szańkowski and Kłosowski, 2001). Data on 
the ecology of submerged lake vegetation (Kłosowski, 2006; Szańkowski and Kłosowski, 2006) and the bioindicator value of the plant communities occurring in astatic water bodies (Kłosowski and Jabłońska, 2009) were assessed.

The present work aims at summarizing the results of ecological studies conducted among the submerged and floating-leaved plant communities of the class Potametea occurring in the lakes of north-eastern Poland. The main objectives of the study were to determine the main environmental factors that best differentiate the habitats of the plant communities studied and the connection between plant communities and various stages of succession, establish the (bio)indicator value of plant communities, and discuss the results obtained and their relevance to the Water Framework Directive.

\section{Material and methods}

Phytosociological and habitat data were collected during the peak growing season (July-August) from 1978 to 2005. Due to the distinct character of the littoral zone of lakes (Pieczyńska, 1972; Planter, 1973) and hydrochemical differences even between neighbouring patches of vegetation within the various bodies of water (Úlehlová and Pribil, 1978; Gaudet and Muthuri, 1981; Kłosowski, 1992), the investigations were carried out on particular phytocoenoses, regardless of the trophic state of the lake. The patches were selected on the basis of floristic dominance. A total of 356 phytocoenoses of the class Potametea from 128 lakes were investigated (Fig. 1). The phytocoenoses dominated by the following 15 species were considered in the study (in brackets number of investigated phytocoenoses): Hydrilla verticillata (L. f.) Royle (14), Ceratophyllum demersum L. (25), Ranunculus circinatus Sibth. (20), Elodea canadensis Michx. (20), Myriophyllum verticillatum L. (24), Myriophyllum spicatum L. (26), Potamogeton perfoliatus L. (28), Potamogeton lucens L. (32), Potamogeton natans L. (33), Nuphar lutea (L.) Sibth. et Sm. (17), Nuphar pumila (Timm) DC (18), Nymphaea alba L. (21), Nymphaea candida C. Presl (30), Polygonum amphibium L. (18) and Stratiotes aloides L. (30).

In each phytocoenosis one phytosociological relevé (10-25 $\mathrm{m}^{2}$ plot) was recorded, and water depth was measured at the deepest and shallowest point of the phytocoenosis taking into account the slope of lake bottom. The abundance of each species within the relevé area was counted according to a modified Braun-Blanquet scale in which $+=\mathrm{a}$ few scattered specimens, mean coverage $0.1 \% ; 1=1-10 \%$ coverage, mean $5 \% ; 2=10-25 \%$ coverage, mean $17.5 \% ; 3=25-50 \%$ coverage, mean $37.5 \%$; $4=50-75 \%$ coverage, mean $62.5 \% ; 5=75-100 \%$ coverage, mean $87.5 \%$. All the relevés recorded in the investigated phytocoenoses were aggregated into one synoptic phytosociological table. In addition, the constancy of each species was counted according to the following scale: $\quad I=$ species present in $1-20 \%$ of relevés; $\mathrm{II}=21-40 \%$; III $=41-60 \%$; IV $=61-80 \% ; \mathrm{V}=81-100 \%$.

In each phytocoenosis (within the relevé area) one water and one substrate sample were taken for physical and chemical analyses (356 water and 356 substrate samples in total). Both water and substrate samples were collected at the same time as the relevés were assessed (July-August). Water samples were taken from an intermediate depth at which a given phytocoenosis occurred and transferred to two $1000 \mathrm{~mL}$ plastic containers. Half of the water samples were preserved by the addition of $1 \mathrm{~mL}$ concentrated $\mathrm{H}_{2} \mathrm{SO}_{4}$ for $\mathrm{PO}_{4}{ }^{3-}, \mathrm{NH}_{4}{ }^{+}, \mathrm{NO}_{3}^{-}$, total $\mathrm{Fe}$ and $\mathrm{COD}-\mathrm{KMnO}_{4}$ analyses. Substrate samples were taken from the rhizome-root layer with a tubular bottom sampler and transferred to plastic bags. Each sample was a mixture of three random subsamples taken within a phytocoenosis. Both water and substrate samples were transported to the laboratory within 3-5 h of collection and the determinations were carried out immediately. Prior to the analyses, the samples were filtered and stored at $4{ }^{\circ} \mathrm{C}$ until all analyses were performed. Altogether 14 physical and chemical parameters of water, 12 of the substrate, mean water depth in which the phytocoenoses occurred and lake surface area were determined.

The following analyses were carried out on water samples: $\mathrm{pH}$ using $\mathrm{pH}$-meter; total hardness using Warthy-Pfeifer sodium mixture and by titration with EDTA reagent and Man Ver 2 as indicator; carbonate hardness by titration with $0.01 \mathrm{~N} \mathrm{HCl}$ using methyl orange as an indicator; chemical oxygen demand (COD) as consumption of $\mathrm{KMnO}_{4}$ in acid medium; $\mathrm{PO}_{4}{ }^{3-}$ spectrophotometrically by the molybdate method; $\mathrm{NO}_{3}{ }^{-}$spectrophotometrically with phenoldisulphonic acid; $\mathrm{NH}_{4}{ }^{+}$ by distillation and spectrophotometrically by Nessler's method; total Fe spectrophotometrically by the rhodanate method; dissolved $\mathrm{SiO}_{2}$ spectrophotometrically by the molybdate method; $\mathrm{SO}_{4}{ }^{2-}$ spectrophotometrically by the nephelometric method; colour spectrophotometrically according to the platinum-cobalt scale; $\mathrm{Ca}^{2+}, \mathrm{Na}^{+}$and $\mathrm{K}^{+}$ with a flame spectrophotometer Flapho 4. Concentrations of $\mathrm{K}^{+}$and $\mathrm{Na}^{+}$were determined in $100 \mathrm{~mL}$ solutions extracted with $2 \mathrm{~mL} \mathrm{HCl} 1+1$ (mixture of one part of concentrated acid to one part of demineralized water from evaporated and ignited $100 \mathrm{~mL}$ samples of water).

In the substrate samples, $\mathrm{pH}$ was assessed in pore water. Concentrations of dissolved $\mathrm{SiO}_{2}$ and $\mathrm{NO}_{3}{ }^{-}$were determined in solutions extracted by the addition of $100 \mathrm{~mL}$ of demineralized water to a substrate sample containing $1 \mathrm{~g}$ of dry matter (water extracts). In the case of solutions used for determinations of total $\mathrm{Fe}, \mathrm{PO}_{4}{ }^{3-}$, $\mathrm{Ca}^{2+}$ and $\mathrm{SO}_{4}{ }^{2-}$, each substrate sample containing $1 \mathrm{~g}$ of dry matter was first digested in $20 \mathrm{~mL} \mathrm{HCl} 1+1$ for $2 \mathrm{~h}$ and then $100 \mathrm{~mL}$ of demineralized water was added (acid extracts). After $24 \mathrm{~h}$ all the extracted solutions (water and acid) were filtered, rinsed with small amounts of demineralized water and the final quantities of the extracted solutions were adjusted to $250 \mathrm{~mL}$. Hydration (water content) was determined by drying substrate samples at $105^{\circ} \mathrm{C}$ to constant weight, organic matter content by 


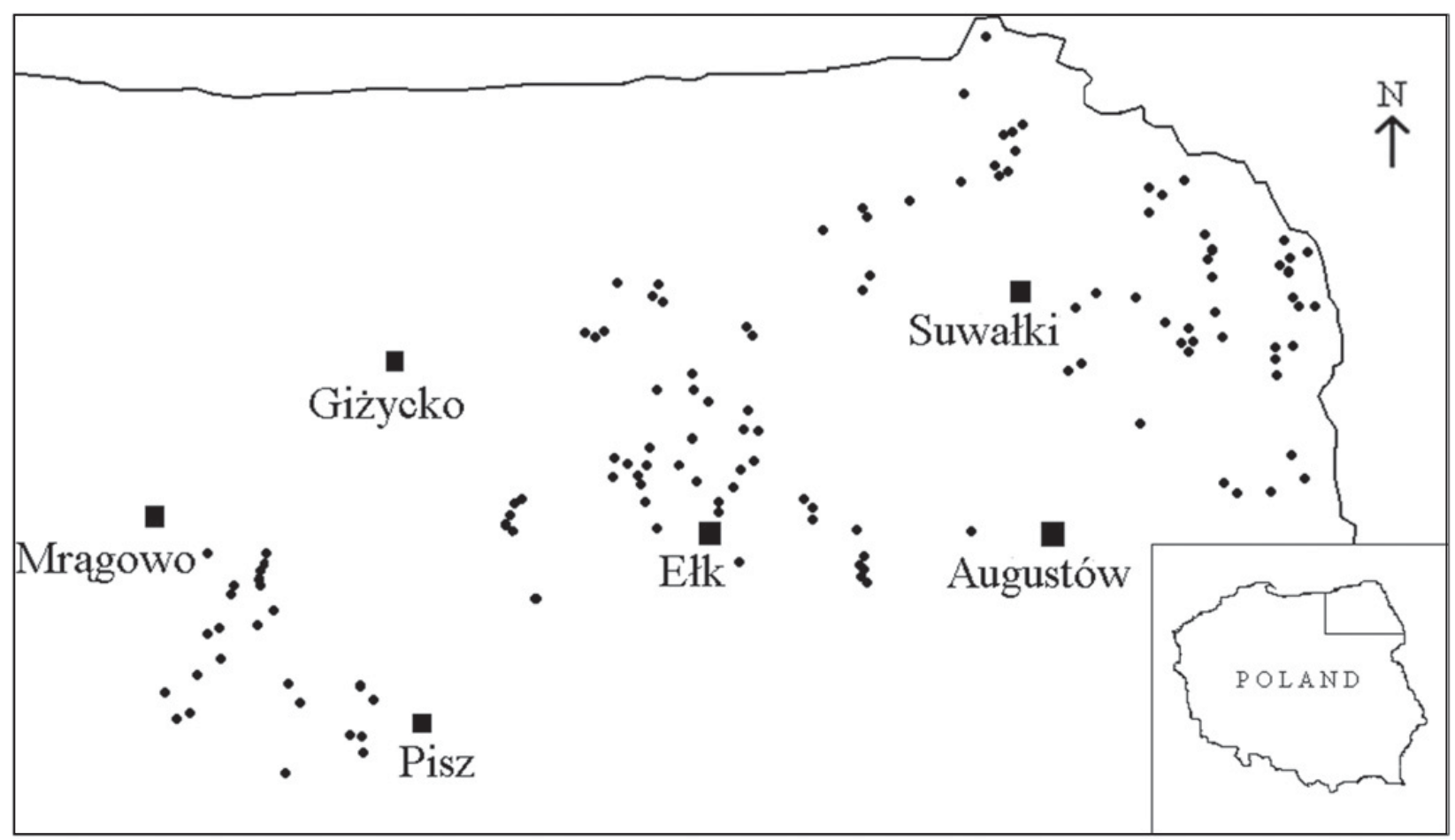

Fig. 1. The study area in north-eastern Poland. The dots represent the lakes that have been sampled.

ignition of dry samples at $550{ }^{\circ} \mathrm{C}$ for $1.5 \mathrm{~h}$ and total $\mathrm{N}$ by Kjeldahl's method. The concentrations of $\mathrm{K}^{+}$and $\mathrm{Na}^{+}$in substrate were determined in $100 \mathrm{~mL}$ solutions extracted with $2 \mathrm{~mL} \mathrm{HCl} 1+1$ from dried and ignited samples. The analyses from water and acid extracts, and the determinations of $\mathrm{Na}^{+}, \mathrm{K}^{+}$and $\mathrm{pH}$ were conducted by the methods described above.

Most of the determinations of water and substrate properties were carried out by methods described by Hermanowicz et al. (1999). Determinations of total hardness were performed according to the procedures described by Hermanowicz et al. (1999) and Hach Company (1992).

\section{Data processing}

The relationships between species composition of vegetation types were analysed by indirect ordination in CANOCO for Windows Version 4.0 (Ter Braak and Šmilauer, 1998). Indirect ordination methods were also used to choose between unimodal or linear ordination methods based on the lengths of gradient (DCA) and in search of arch-effect and outliers (CA).

The relationships between habitat factors and vegetation were analysed by direct ordination in CANOCO for Windows v. 4.0 (Ter Braak and Šmilauer, 1998). As the length of gradient in DCA exceeded $3 \mathrm{SD}$ - CCA was used (Jongman et al., 1987). To avoid using strongly correlated variables in CCA, a variance inflation factor was analysed - no habitat variable showed a high correlation with the other variables (VIF $>20, c f$. Ter Braak, 1986), so there was no need to remove any variable from the analysis on the basis of VIF values. A forward selection was performed to determine which variables have the greatest effect on macrophyte ecology. Only variables that were significant $(p<0.05)$ and explained more than $0.5 \%$ of the overall species diversity were used in the final CCA analysis. The significance of CCA (first canonical axis and all canonical axes) was tested with the Monte-Carlo permutation test, using unrestricted permutations.

The habitat conditions of the 15 types of phytocoenoses investigated were compared with respect to each property using quartiles. The significance of differences in water and substrate properties between the plant communities studied was determined by the KruskalWallis test and non-parametric multiple comparisons (Zar, 1984).

\section{Results}

\section{Characteristics of the phytocoenoses studied}

The phytocoenoses studied were characterized by a strong dominance of one species, i.e., species with high constancy (class V) and cover (3-5 according to the Braun-Blanquet scale) (Table 1). Patches of $R$. circinatus, E. canadensis, $P$. perfoliatus, $M$. spicatum and $P$. amphibium had a higher frequency of species with submerged leaves than floating-leaved species among the Potametea species. Phytocoenoses of E. canadensis and P. perfoliatus were characterized by a higher proportion of Lemna trisulca L. Patches with M. verticillatum, C. demersum, 
284

S. Kłosowski et al.: Ann. Limnol. - Int. J. Lim. 47 (2011) 281-295

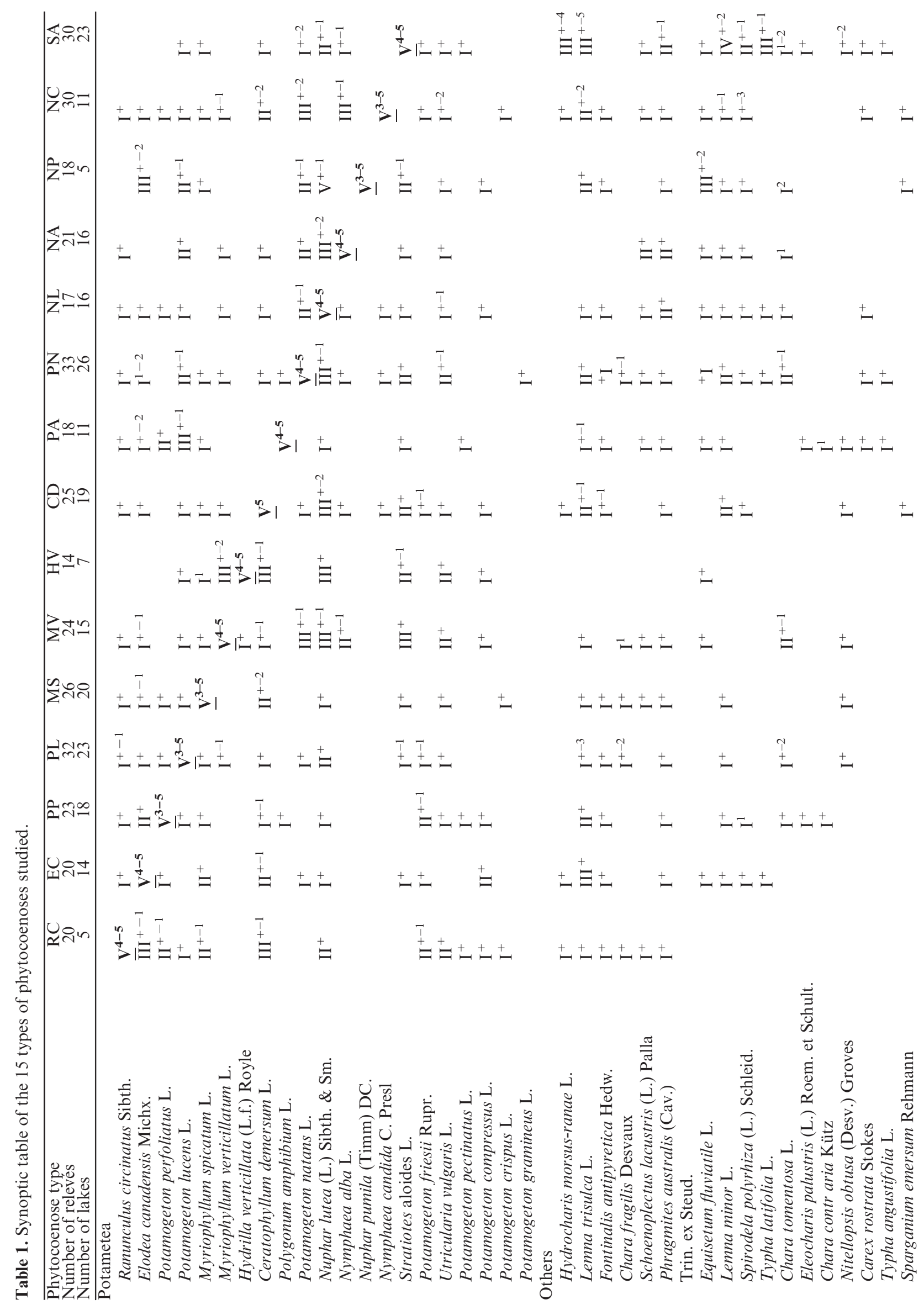




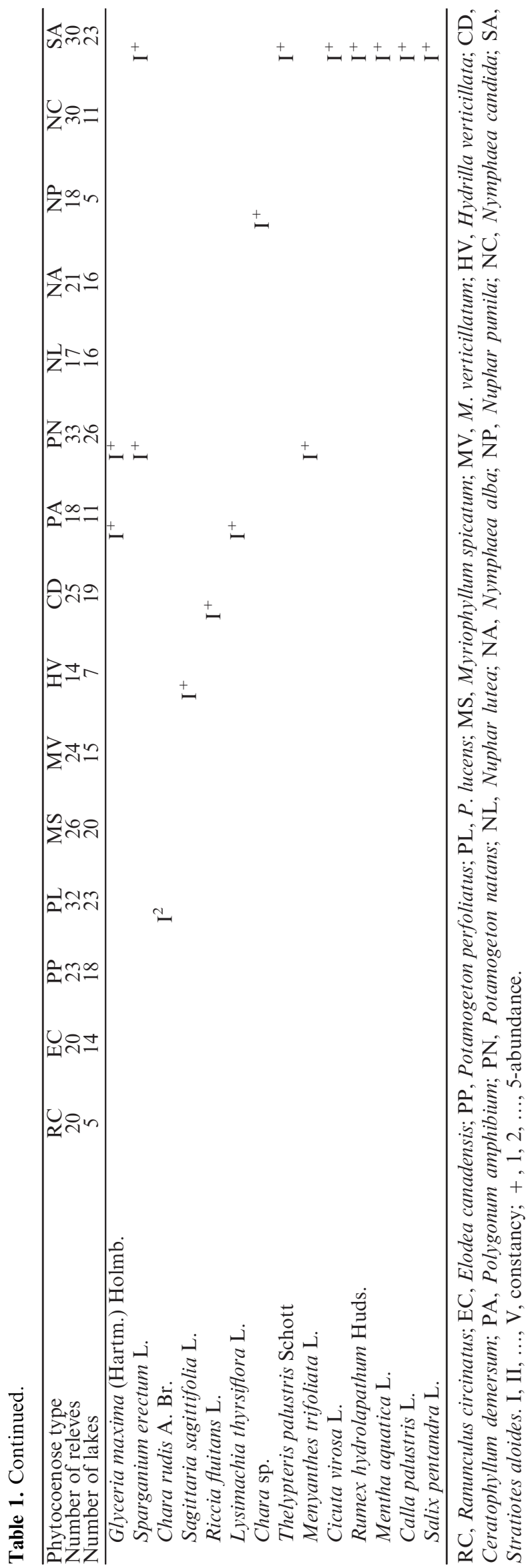

P. natans, P. lucens, N. alba, N. candida and N. lutea typically included more floating-leaved species. Both submerged and floating-leaved species were noted frequently in the phytocoenoses dominated by $H$. verticillata and $N$. pumila. The $S$. aloides phytocoenoses had the highest proportion of free-floating species such as Lemna minor L., L. trisulca and Hydrocharis morsus-ranae L. Reed swamp species did not play an important role in the structure of the communities studied, with the exception of Equisetum fluviatile L. in the phytocoenoses of $N$. pumila, Typha latifolia L. in the phytocoenoses of $S$. aloides and Phragmites australis (Cav.) Trin. ex Steud. in the patches of $P$. amphibium, N. lutea, N. alba and S. aloides.

\section{Environmental properties}

The differentiation of the 15 types of phytocoenoses in relation to environmental properties (amplitude, interquartile ranges of values and medians) is shown in Figure 2 (see Appendix 1 online supporting material at www.limnology-journal.org for the significances of differences). In CCA we took into account 24 variables (Table 2). The four main ordination axes showed high eigenvalues $(\lambda)$ : I $-\lambda_{1}=0.655, \mathrm{II}-\lambda_{2}=0.527$, III $-\lambda_{3}=0.473$, IV $-\lambda_{4}=0.543$, respectively. Therefore, we analysed the phytocoenosis-habitat relationships along a gradient of all four axes (Figs. 3-5). Here we focus on discussing those variables that were most strongly correlated with the ordination axes.

The analysis of the first and second ordination axes (Fig. 3) revealed that the properties that best differentiated the habitats of the communities studied were hydration, organic matter, total $\mathrm{N}, \mathrm{PO}_{4}{ }^{3-}$, dissolved $\mathrm{SiO}_{2}$ (in the case of substrates), $\mathrm{Na}^{+}$(in the case of water) as well as lake surface area. All the above-mentioned variables were correlated with the first ordination axis. Water variables correlated with the second ordination axis, such as $\mathrm{pH}$, $\mathrm{Ca}^{2+}, \mathrm{NO}_{3}{ }^{-}$and $\mathrm{COD}-\mathrm{KMnO}_{4}$, also played an important role in differentiating the habitats. Hydration, organic matter and total $\mathrm{N}$ content differentiated the substrates of the communities studied into two groups. Low values of these parameters were found for $P$. amphibium, $M$. spicatum, $P$. perfoliatus and $R$. circinatus phytocoenoses, whereas $C$. demersum, $N$. candida, N. alba, $M$. verticillatum, $N$. pumila, $H$. verticillata and $S$. aloides were distinguished by high values. P. lucens, E. canadensis and $N$. lutea occupied an intermediate position. The first four types of phytocoenoses were restricted mainly to large lakes, whereas the remaining communities were usually found in smaller lakes. The $\mathrm{PO}_{4}{ }^{3-}$ content and dissolved $\mathrm{SiO}_{2}$ differentiated the substrates of the communities studied in a different manner. The highest values of $\mathrm{PO}_{4}{ }^{3-}$ were recorded in the substrates of $R$. circinatus, with lower levels for $C$. demersum, and the lowest values in the case of $S$. aloides, $N$. pumila and $N$. lutea. The concentration of dissolved $\mathrm{SiO}_{2}$ showed the opposite trend compared to that of $\mathrm{PO}_{4}^{3-}$. $\mathrm{Na}^{+}$concentration and $\mathrm{pH}$ in water differentiated the communities studied in the same 

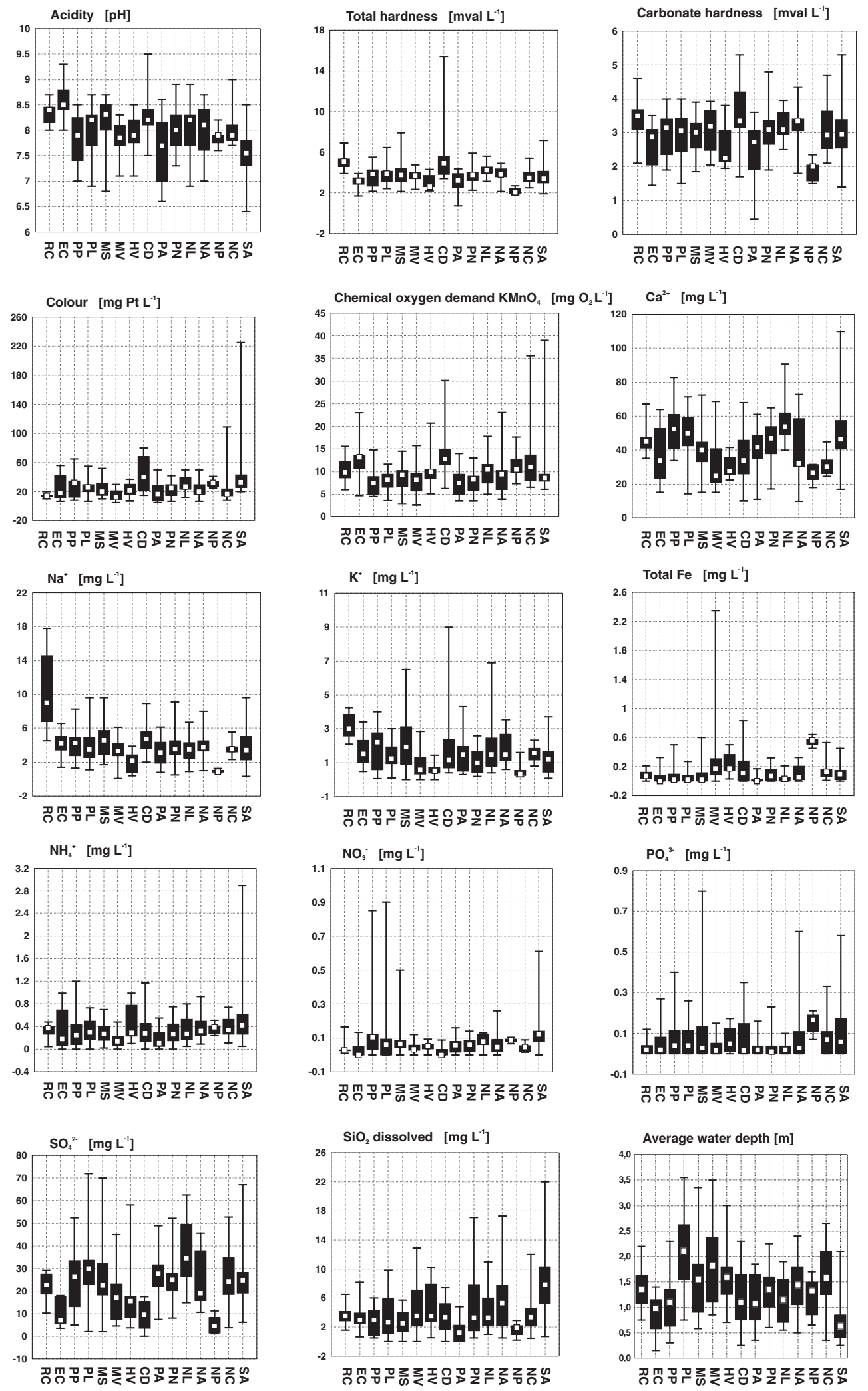

Fig. 2. Differentiation of the 15 types of water plant phytocoenoses studied in relation to (a) 14 physicochemical properties of water and mean water depth in which the phytocoenoses occurred and (b) 12 physicochemical properties of substrate and lake surface area. Black boxes indicate $25-75 \%$ interquartile ranges of values and white boxes show the medians. Abbreviations of phytocoenoses (dominant species): RC, Ranunculus circinatus; EC, Elodea canadensis; PP, Potamogeton perfoliatus; PL, P. lucens; MS, Myriophyllum spicatum; MV, M. verticillatum; HV, Hydrilla verticillata; CD, Ceratophyllum demersum; PA, Polygonum amphibium; PN, Potamogeton natans; NL, Nuphar lutea; NA, Nymphaea alba; NP, Nuphar pumila; NC, Nymphaea candida; SA, Stratiotes aloides. 

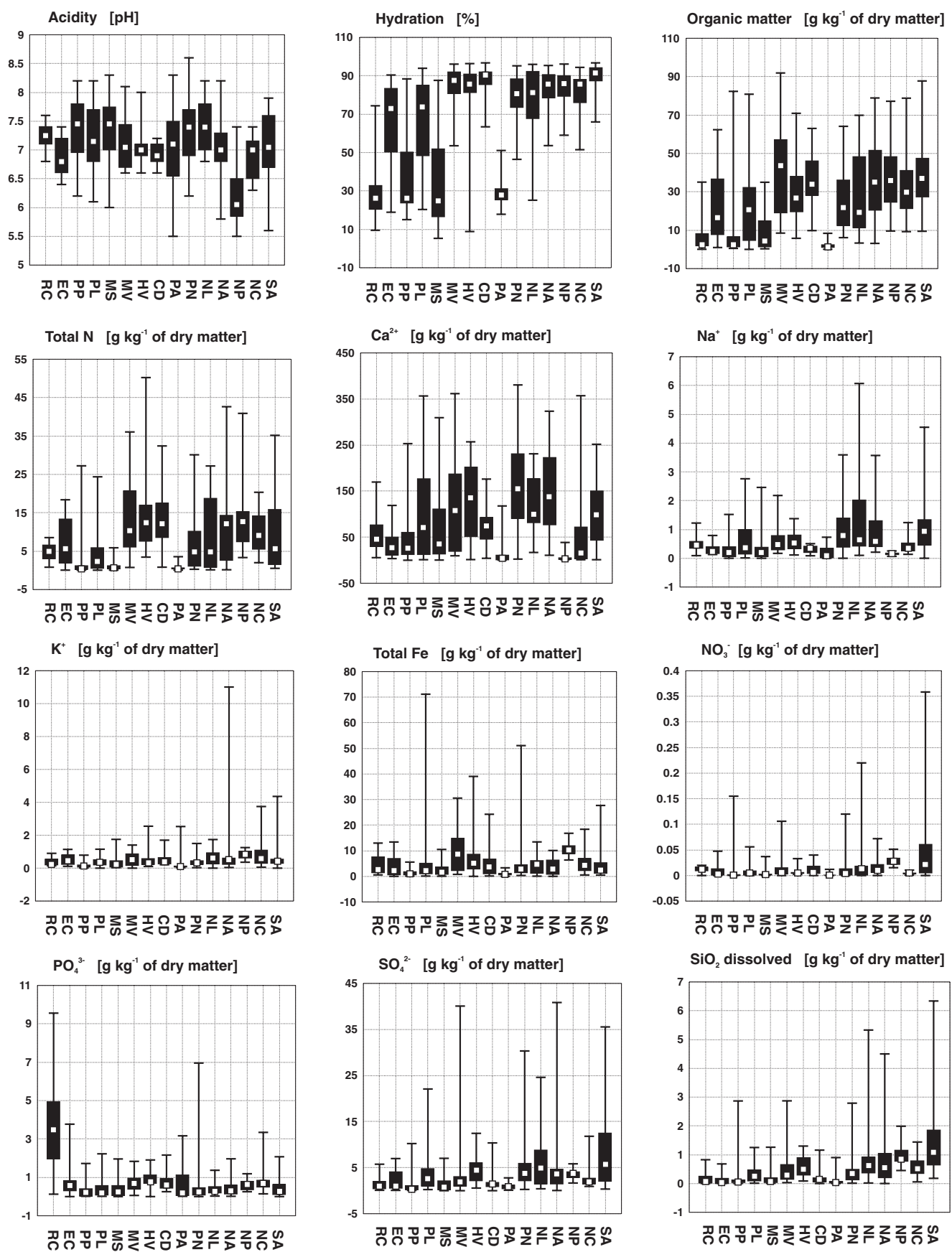

$\mathrm{SiO}_{2}$ dissolved [ $\mathrm{g} \mathrm{kg}^{-1}$ of dry matter]
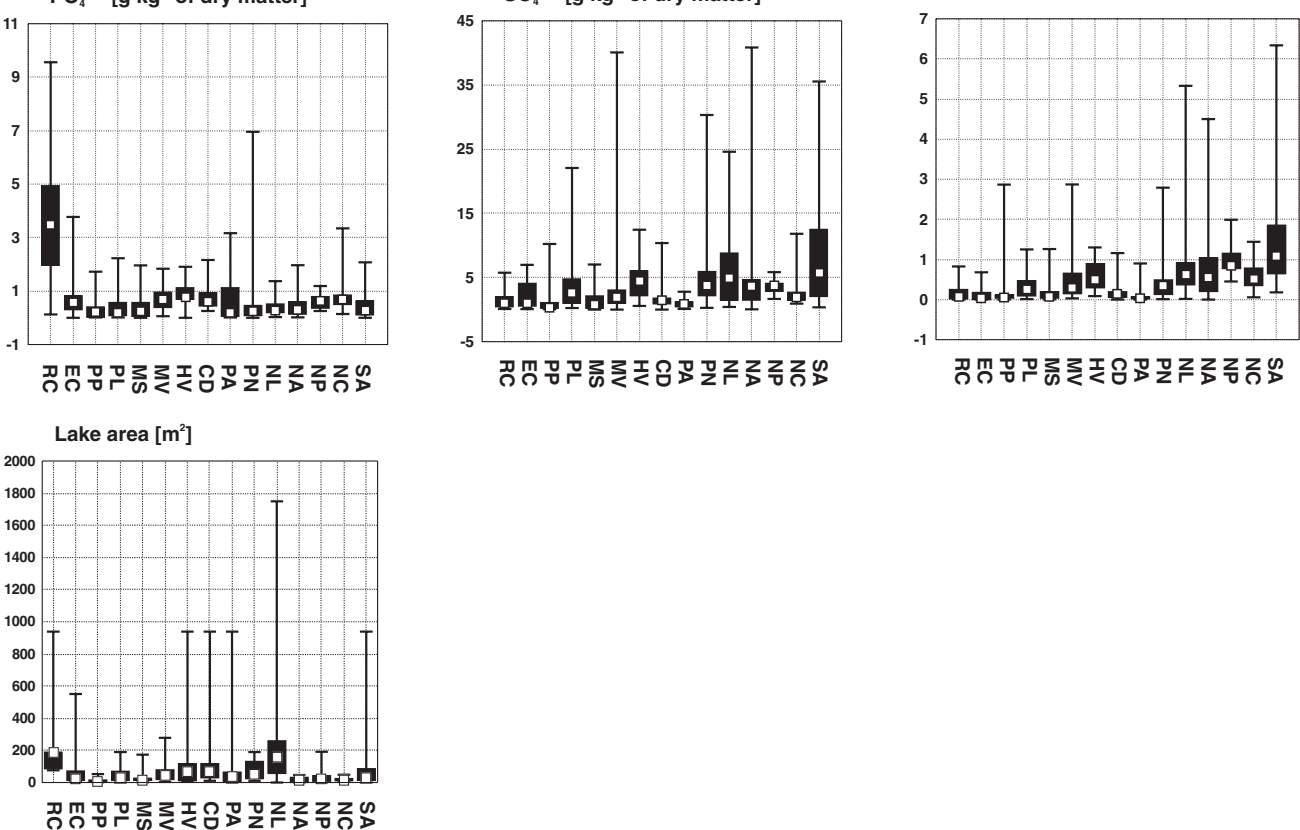

Fig. 2. Continued. 
Table 2. Correlation coefficient of environmental variables with CCA axes.

\begin{tabular}{|c|c|c|c|c|}
\hline Axes & I & II & III & IV \\
\hline S-pH & 0.2061 & 0.1425 & 0.2936 & -0.1839 \\
\hline S-hydration & -0.6995 & -0.2610 & -0.0262 & -0.2121 \\
\hline $\mathrm{S}$-organic $\mathrm{n}$ & -0.5235 & -0.1878 & -0.0234 & -0.1399 \\
\hline S-total N & -0.3728 & -0.2466 & -0.1068 & -0.0637 \\
\hline $\mathrm{S}-\mathrm{Ca}^{2+}$ & -0.1671 & -0.0277 & 0.2815 & -0.2124 \\
\hline $\mathrm{S}-\mathrm{Na}^{+}$ & -0.1772 & 0.1200 & 0.1143 & -0.3140 \\
\hline S-total $\mathrm{Fe}$ & -0.1777 & -0.1060 & 0.0199 & 0.0721 \\
\hline $\mathrm{S}-\mathrm{NO}_{3}^{-}$ & -0.1917 & 0.1621 & -0.2025 & -0.2428 \\
\hline $\mathrm{S}-\mathrm{PO}_{4}^{3}$ & 0.4369 & -0.2741 & -0.1729 & -0.1406 \\
\hline -dissol & -0.3277 & 0.1847 & -0.1496 & -0.2408 \\
\hline$-\mathrm{pH}$ & & -0 & -0 . & 0.0734 \\
\hline to & & -0.2679 & 527 & -0.3115 \\
\hline $\begin{array}{l}\text { W-car } \\
\text { hard }\end{array}$ & 0.0730 & -0.1844 & 0.1646 & -0.3724 \\
\hline W-col & -0.23 & & -0.19 & -0.1993 \\
\hline $\mathrm{W}-\mathrm{COD}-\mathrm{KMnO}_{4}$ & -0.1208 & -0.2584 & -0.2257 & -0.0943 \\
\hline $\mathrm{W}-\mathrm{Ca}^{2+}$ & 0.1204 & 0.3214 & 0.0470 & -0.3342 \\
\hline $\mathrm{W}-\mathrm{Na}^{+}$ & 0.5370 & -0.2090 & -0.0448 & -0.3228 \\
\hline W-to & -0.2857 & -0.1350 & -0.1546 & 0.2749 \\
\hline & -0.0959 & 0.3249 & -0.1063 & -0.1360 \\
\hline W-PC & -0.1288 & 0.0844 & -0.1489 & 0.0347 \\
\hline & & 0.2832 & 0.3421 & -0.2377 \\
\hline & -0.2368 & 0.0686 & -0.0190 & -0.3839 \\
\hline & & -0.1985 & 0.4482 & 0.1869 \\
\hline Lake area & 0.3059 & 0.1415 & -0.0866 & -0.0761 \\
\hline
\end{tabular}

S, substrate; W, water.

way as $\mathrm{PO}_{4}{ }^{3-}$ in substrates. Levels of $\mathrm{Ca}^{2+}$ in waters of the communities studied differed considerably. The highest values of $\mathrm{Ca}^{2+}$ were detected in the waters of $P$. perfoliatus and $N$. lutea, and the lowest in those of $N$. candida, $M$. verticillatum, $N$. pumila, $H$. verticillata and $C$.demersum (Fig. 2). Communities of S. aloides, P. perfoliatus, N. lutea and $N$. pumila were distinguished from those of $C$. demersum, E. canadensis and $N$. candida by much higher values of $\mathrm{NO}_{3}^{-}$. COD- $\mathrm{KMnO}_{4}$ is used to estimate the amount of dissolved organic matter in water. This parameter differentiated the habitats of the communities studied into two groups. The phytocoenoses of $P$. perfoliatus, $P$. amphibium, $P$. lucens and $S$. aloides were associated with waters containing low amounts of dissolved organic matter, whereas those of $C$. demersum, $E$. canadensis and $N$. candida developed in waters rich in dissolved organic matter.

The third ordination axis (Fig. 4) represents most of the variance resulting from differentiation of the plant communities in relation to water depth, $\mathrm{SO}_{4}{ }^{2-}$ concentration in the water, substrate $\mathrm{pH}$ and substrate $\mathrm{Ca}^{2+}$ content. These four parameters were most strongly correlated with the third ordination axis (Table 2). The deepest parts of lakes were inhabited by phytocoenoses of $P$. lucens, $M$. verticillatum and $N$. candida. The $S$. aloides and E. canadensis phytocoenoses were associated with the shallowest waters (Fig. 2). $\mathrm{SO}_{4}{ }^{2-}$ concentration differentiated waters of the communities studied into two groups. The first group included phytocoenoses of $P$. lucens and $N$. lutea developed in waters with the highest concentration of $\mathrm{SO}_{4}{ }^{2-}$ (Fig. 2). The second group included $N$. pumila, $C$. demersum, E. canadensis and $H$. verticillata and formed in waters poor in $\mathrm{SO}_{4}{ }^{2-}$. The substrates of the communities studied differed considerably with respect to $\mathrm{pH}$. The $N$. pumila phytocoenoses were associated with the most highly acidic substrates, whereas $P$. perfoliatus, $M$. spicatum and $R$. circinatus inhabited alkaline substrates (Fig. 2). Substrates of $P$. natans, $N$. alba, $H$. verticillata and $S$. aloides communities had the highest content of $\mathrm{Ca}^{2+}$, whereas $N$. pumila, $P$. amphibium, $P$. perfoliatus and $E$. canadensis inhabited substrates poorer in $\mathrm{Ca}^{2+}$.

The fourth axis (Fig. 5) represents most of the variance resulting from habitat differentiation in relation to $\mathrm{Ca}^{2+}$ concentration in water, total hardness and carbonate hardness, as well as $\mathrm{Na}^{+}$content in the substrates. Particularly noteworthy were patches of $N$. pumila that developed in soft waters poor in $\mathrm{Ca}^{2+}$, and those of $R$. circinatus associated with hardest waters. The $H$. verticillata phytocoenoses were also found in relatively soft waters containing low amounts of $\mathrm{Ca}^{2+}$, whereas $N$. lutea showed preference for harder waters having higher concentrations of $\mathrm{Ca}^{2+}$ (Fig. 2).

Among the remaining properties, the total Fe concentration in water is worthy of note. This parameter was correlated to a similar degree with the first and fourth ordination axes (Table 2). The highest values of total $\mathrm{Fe}$ were noted in the waters of $N$. pumila, and lowest values in those of $P$. amphibium (Fig. 2).

\section{Discussion}

The results obtained in this study indicate that in spite of the highly unstable habitat and biotope conditions in the littoral zone dominated by macrophyte communities and the high degree of plasticity of aquatic plants (Hinneri, 1976; Willby et al., 2000, Chambers et al., 2008), clear relationships exist between particular types of phytocoenoses and their habitats. In addition to the depth in which the phytocoenoses occurred and the lake surface area, these vegetation-habitat relationships include both water and substrate properties. The water properties that best differentiated the habitats of the aquatic plant associations studied were $\mathrm{Na}^{+}, \mathrm{SO}_{4}{ }^{2-}$, dissolved $\mathrm{SiO}_{2}$, total $\mathrm{Fe}, \mathrm{Ca}^{2+}$ and water hardness, $\mathrm{pH}$, dissolved organic matter $\left(\mathrm{COD}-\mathrm{KMnO}_{4}\right)$ and $\mathrm{NO}_{3}{ }^{-}$. The substrates compared were best differentiated by the following properties: hydration, organic matter, total $\mathrm{N}, \mathrm{PO}_{4}{ }^{3-}$, dissolved $\mathrm{SiO}_{2}$, $\mathrm{Ca}^{2+}, \mathrm{Na}^{+}$and $\mathrm{pH}$.

The greatest differences between the habitats of the associations studied were found in the case of $R$. circinatus (larger lakes, hard, alkaline waters that are particularly rich in $\mathrm{Na}^{+}$, and mineral substrates with high $\mathrm{PO}_{4}{ }^{3-}$ content) and $N$. pumila (small lakes, soft waters that are particularly poor in $\mathrm{Na}^{+}$and $\mathrm{SO}_{4}{ }^{2-}$, but rich in total $\mathrm{Fe}$, and acidic substrates containing low amounts of $\mathrm{Ca}^{2+}$ ). The remaining plant communities compared in this study were usually distinguished by several properties, 


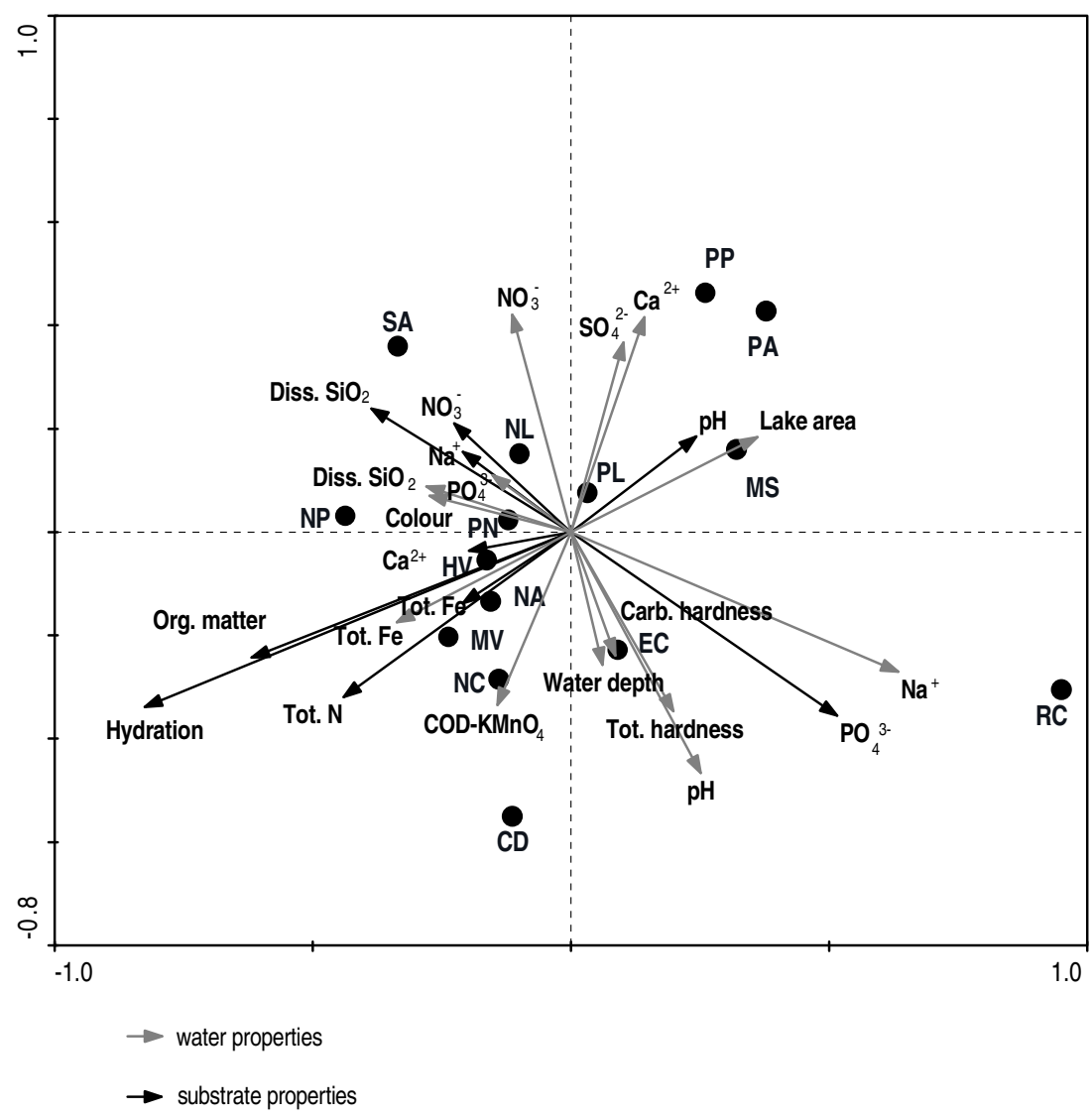

Fig. 3. CCA ordination diagram of I and II axes obtained from 356 relevés and 12 water properties, mean water depth in which the phytocoenoses occurred, lake surface area and 10 substrate properties. The dominant species of the 15 types of water plant phytocoenoses studied were plotted. Eigenvalues: $\lambda_{1}=0.655, \lambda_{2}=0.527, \lambda_{3}=0.473, \lambda_{4}=0.453$. The significance of first canonical axis and all canonical axes tested with Monte-Carlo permutation test: $p<0.01$. See Figure 2 for the abbreviations of phytocoenoses.

e.g., C. demersum and E. canadensis (small lakes, alkaline waters rich in dissolved organic matter), and $S$. aloides (very shallow waters, strongly hydrated substrates, both water and substrate rich in dissolved $\mathrm{SiO}_{2}$ ).

How do our findings compare with those of other authors, aimed at developing universal methods of assessing the ecological status of lakes and rivers based on macrophyte composition (European Commission, 2000). The majority of these other studies are concerned with the relationships between macrophytes and water quality in bodies of water (Pietsch, 1972; Wiegleb, 1978; Papastergiadou and Babalonas, 1993a, 1993b; Lukács et al., 2009; Lumbreras et al., 2008). Many authors take into account the general limnological conditions in a lake, such as its morphometry (size and shape of the lake basin) and/or geographical coordinates, when investigating the occurrence of aquatic plants and their communities (Vestergaard and Sand-Jensen, 2000; Heegaard et al., 2001; Mäkelä et al., 2004; McElarney and Rippey, 2009; Free et al., 2009; Del Pozo et al., 2010; Sass et al., 2010). The present studies were consistently conducted within dense stands of macrophytes from which the water and substrate samples were taken for analysis and the particular properties were determined. It seems, therefore, difficult to compare such data. However, in the case of water, the results of our study confirmed the findings of other authors, who point to the important role of properties associated with the carbonate system in differentiating the habitats of aquatic plant communities (Wiegleb, 1978; Kadono, 1982; Kunii, 1991; Papastergiadou and Babalonas, 1993a, 1993b; Toivonen and Huttunen, 1995; Vestergaard and Sand-Jensen, 2000). Changes in the carbonate system affect the amount of available inorganic carbon as well as such properties as water hardness, $\mathrm{pH}$, and $\mathrm{Ca}^{2+}$ and $\mathrm{Na}^{+}$concentrations. The properties indicating water richness, such as $\mathrm{COD}-\mathrm{KMnO}_{4}, \mathrm{NO}_{3}^{-}$ and $\mathrm{PO}_{4}^{3-}$, appear to be important as well, but not as important as the factors associated with the carbonate system, which may be attributed to the small differences in the trophic state of the lakes studied (from slightly eutrophic to eutrophic lakes). Similar observations were also made by others (Jackson and Charles, 1988; Kunii, 1991; Mäkelä et al., 2004).

Our results are in agreement with the data reported from works of other authors for most of the investigated plant communities. For example, the relationship of $C$. demersum to hard, alkaline waters was indicated by Moyle (1945), Kadono (1982), Pietsch (1982), De Lyon and Roelofs (1986a, 1986b), Pip (1988), Papastergiadou and Babalonas (1993a, 1993b) and Vestergaard and 


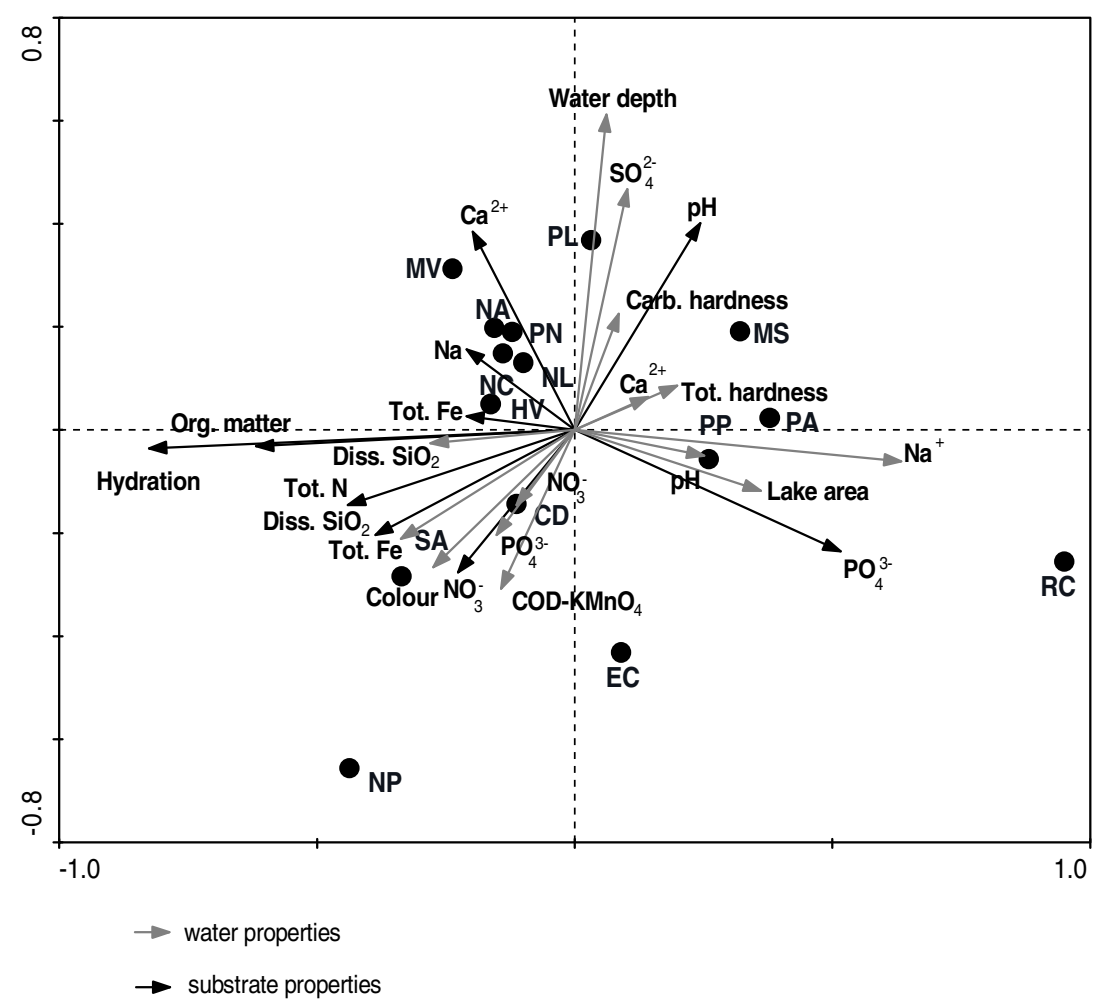

Fig. 4. CCA ordination diagram of I and III axes obtained from 356 relevés and 12 water properties, average water depth in the phytocoenoses, lake surface area and 10 substrate properties. The dominant species of the 15 types of water plant phytocoenoses studied were plotted. Eigenvalues: $\lambda_{1}=0.655, \lambda_{2}=0.527, \lambda_{3}=0.473, \lambda_{4}=0.453$. The significance of first canonical axis and all canonical axes tested with Monte-Carlo permutation test: $p<0.01$. See Figure 2 for the abbreviations of phytocoenoses.

Sand-Jensen (2000). Similar observations were made with regard to $R$. circinatus (e.g., Wiegleb, 1978; Pietsch, 1982; De Lyon and Roelofs, 1986a, 1986b). Lumbreras et al. (2008) pointed to the great variety of habitats of plant communities dominated by various aquatic Ranunculus species. In their recent publication, Lukács et al. (2009) reported that the phytocoenoses of $P$. lucens occurred in waters rich in $\mathrm{Ca}^{2+}$. Pietsch (1982) indicated that $P$. perfoliatus was also associated with waters with high $\mathrm{Ca}^{2+}$ concentrations, whereas $M$. verticillatum developed best in waters containing low levels of $\mathrm{PO}_{4}{ }^{3-}$. Relatively low concentrations of $\mathrm{P}$ in waters of the latter community were also confirmed by Wiegleb (1978), De Lyon and Roelofs (1986a, 1986b) and Mäkelä et al. (2004). De Lyon and Roelofs (1986a, 1986b) and Heegaard et al. (2001) demonstrated that the phytocoenoses of $M$. spicatum have a broad ecological amplitude with respect to properties of water, and developed best in waters relatively rich in $\mathrm{SO}_{4}{ }^{2-}$.

Our results also confirm the distinct character of the habitats of some floating-leaved plant communities, particularly the phytocoenoses of $N$. pumila, which are found in mostly nutrient-rich (Roweck, 1988; Kozlowski and Eggenberg, 2005) soft waters, poor in $\mathrm{Ca}^{2+}$ (Kadono, 1982; Roweck, 1988; Kłosowski and Tomaszewicz, 1990; Doll, 1991). The results obtained by some authors confirm our findings for $N$. lutea (waters rich in $\mathrm{Ca}^{2+}$ and $\mathrm{NO}_{3}{ }^{-}-$Wiegleb, 1978; hard alkaline waters De Lyon and Roelofs, 1986a, 1986b; Smits et al., 1988), $N$. candida (mesotrophic or slightly eutrophic waters Pietsch, 1982; narrow ecological amplitude with respect to $\mathrm{Ca}^{2+}-$ Van der Velde et al., 1986) and P. amphibium (waters relatively poor in $\mathrm{NH}_{4}{ }^{+}-$Wiegleb, 1978). Some authors, however, present different results regarding the phytocoenoses dominated by a particular species. For example, Wiegleb (1978) and Pietsch (1982) indicated the relationship of $C$. demersum to waters rich in $\mathrm{NO}_{3}{ }^{-}$, which was not confirmed by our study. Perhaps $\mathrm{NH}_{4}{ }^{+}$plays a more important role in influencing the distribution of $C$. demersum. These differences may result from regional differences between the habitats, changes in a number of complex factors and ecological plasticity of aquatic plants.

Despite many methodological differences that exist between studies, our findings concerning the relationship between macrophytes and properties of water agree to a large extent with the results of many other studies. Since the size of the dataset being analysed is large (15 types of phytocoenoses from 128 lakes), it could be used to implement the Water Framework Directive (European Commission, 2000). The data may prove particularly useful in determining specific groups of aquatic macrophytes that can be used as indicators of water quality (sensitive, tolerant and indifferent 


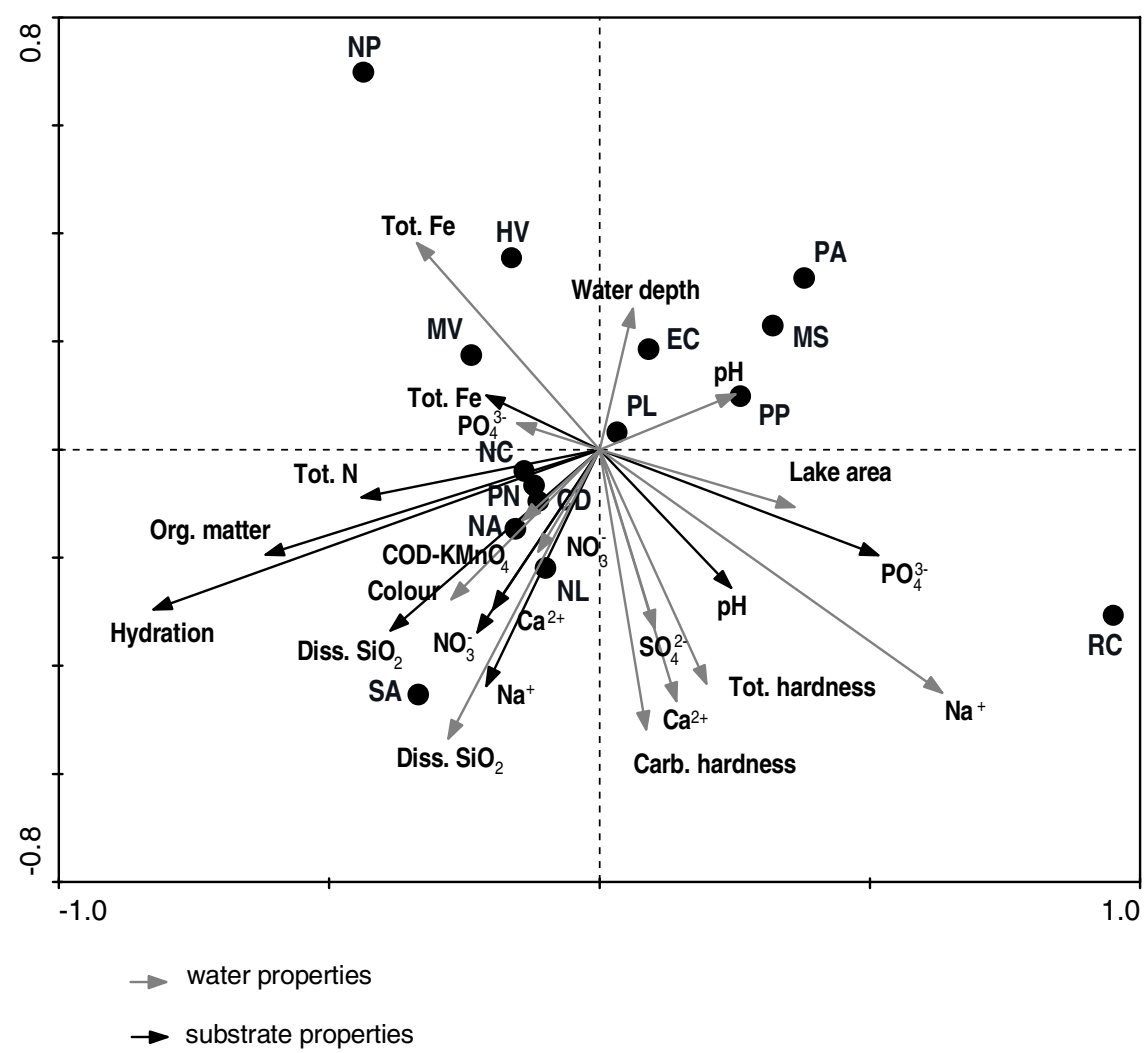

Fig. 5. CCA ordination diagram of I and IV axes obtained from 356 relevés and 12 water properties, average water depth in the phytocoenoses, lake surface area and 10 substrate properties. The dominant species of the 15 types of water plant phytocoenoses studied were plotted. Eigenvalues: $\lambda_{1}=0.655, \lambda_{2}=0.527, \lambda_{3}=0.473, \lambda_{4}=0.453$. The significance of first canonical axis and all canonical axes tested with Monte-Carlo permutation test: $p<0.01$. See Figure 2 for the abbreviations of phytocoenoses.

species - Penning et al., 2008a). Moreover, these data could help increase our knowledge about the ecology and habitat requirements of many species. This is a particularly important task since the data of Penning et al. (2008a) show that in the REBECCA macrophyte database, established to provide scientific support for the implementation of the EU Water Framework Directive, the number of lakes from different countries is not comparable (e.g., Poland - 5 lakes, Romania - 19 lakes, Sweden 254 lakes, Finland - 527 lakes).

The situation is completely different for substrates. Although the role of substrates as an anchorage for roots of aquatic vegetation and nutrient source as well as the place where the decomposition, sedimentation and accretion processes occur has been well recognized (Barko et al., 1991 and literature cited therein), the relationships between plant communities and substrates have been less frequently studied. Hence, there are only a few studies with which to compare our findings. De Lyon and Roelofs (1986a, 1986b) indicated that $P$. perfoliatus and $E$. canadensis occurred frequently on mineral substrates, whereas $C$. demersum, $N$. alba, $N$. candida and S. aloides were associated mostly with organic substrates, which is in agreement with the results of our study. In some phytosociological works, the relationship of $C$. demersum to organic substrates was also demonstrated (e.g., Doll,
1991), and in the case of $N$. alba confirmed by Rejewski (1981). Roweck (1988) and Kozlowski and Eggenberg (2005) indicated that the phytocoenoses of N. pumila were confined to organic substrates. The data obtained by other authors (e.g., De Lyon and Roelofs, 1986a, 1986b; Van Katwijk and Roelofs, 1988) show that the phytocoenoses dominated by species such as P. natans, P. lucens, $N$. lutea, M. spicatum and $M$. verticillatum have a wide ecological amplitude with respect to substrate properties.

It should be noted that substrate data (as opposed to water) have not been used in aquatic macrophyte community indices defining the ecological status of lakes (e.g., trophic indices - TI; lake trophic ranking index - LTR, see Penning et al., 2008b). It is undoubtedly much easier to use water properties (e.g., total P, Secchi depth, chlorophyll- $a$ concentration) to determine the indices. The averaged hydrochemical data can be representative for the lake due to mixing of all the water in the lake. It is difficult to calculate the average values for the properties of substrates from mixed samples taken within the aquatic vegetation growth zone due to the high degree of spatial heterogeneity of the littoral sediments (Spence, 1967, 1982; Nõges and Kisand, 1999; Schmieder and Lehmann, 2004) and the presence of dense stands of macrophytes that differentiate and stabilize the bottom sediments (James and Barko, 1990; Barko et al., 1991). As a result, there is 


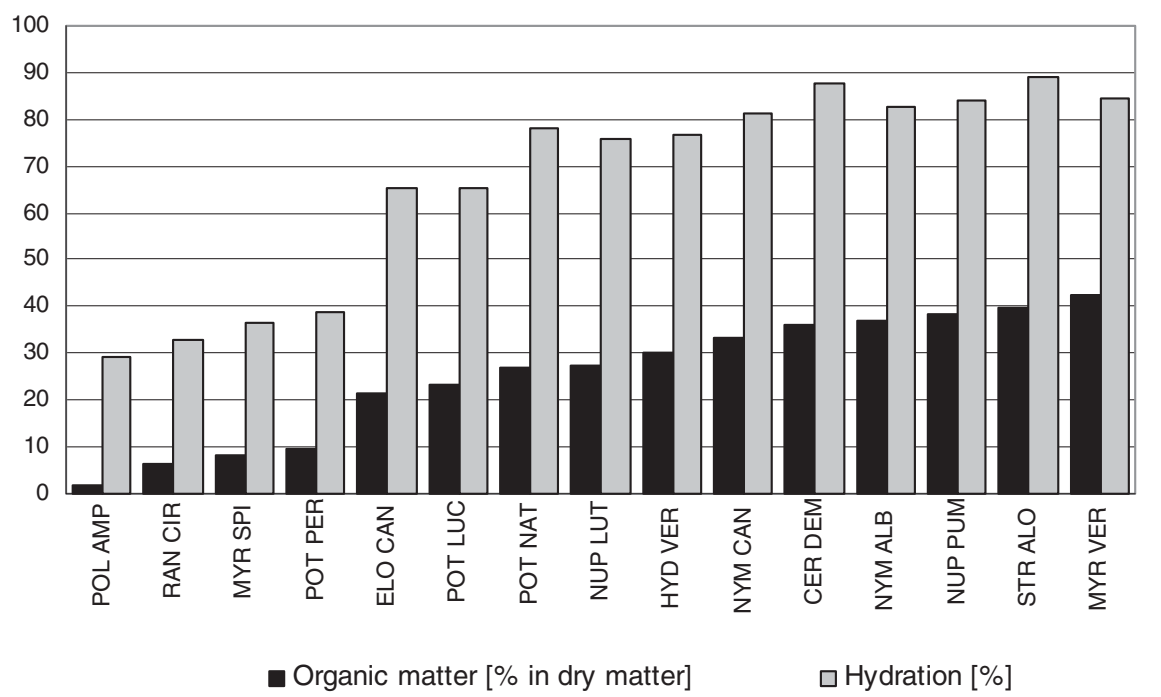

Fig. 6. Mean values of the organic matter content and water content in substrate in the 15 types of water plant phytocoenoses compared.

limited mixing of sediment. Despite many methodological problems, substrate properties should also be considered when assessing the ecological status of lakes, as indicated by Penning et al. (2008b). Therefore the new data on the relationships between aquatic plant communities and substrate properties from the 128 lakes included in our study may prove to be significant.

Our study showed that the substrate properties that best differentiated the habitats of the plant communities were primarily hydration and organic matter content. These parameters could be used in assessing the ecological condition of a lake. Changes in organic matter content and quality in substrates not only affect the vegetation structure but also lead to changes in the species composition of plant communities in the littoral zone (Barko and Smart, 1983, 1986). Since it is generally recognized that sediment deposition and an increase in organic matter content take place during the aging process of lakes (e.g., Misra, 1938; Wilcox and Simonin, 1987; Barko et al., 1991; Van Groenendael et al., 1996), plant communities associated with substrates containing different amounts of organic matter could serve as indicators of the succession process.

Some plant communities are associated with mineral substrates in the early stages of succession, whereas others are confined to organic substrates in the late stages of this process. This is clearly evident when the substrates of all the plant communities investigated in this study (data from several tens of lakes) are arranged in order of increasing organic matter content and degree of hydration (Fig. 6). Sediments in the late stages of succession are highly hydrated in the upper layers (Kłosowski, 1990). Therefore, many plant communities are not able to develop as their dominant species need a firm substrate for anchorage. This eventually leads to the formation of floating mats of vegetation composed of the phytocoenoses of Thelypteris palustris Schott, Cicuta virosa L. or Carex acutiformis Ehrh., which encroach from the lake edges toward the centre. From the open water these communities adjoin the patches of $S$. aloides, which in turn occur beside the phytocoenoses of N. alba, M. verticillatum or $C$. demersum. A similar spatial distribution of plant communities has been observed in a number of very shallow bays of lakes in north-eastern Poland (Tomaszewicz, 1979; Kłosowski, 1990). The phytocoenoses of $R$. circinatus, $P$. perfoliatus, $M$. spicatum and $P$. amphibium dominate in deeper waters of lakes. In places where the sediments are more highly hydrated (less firm) and contain greater amounts of organic matter, the phytocoenoses of $P$. lucens, $P$. natans and $N$. lutea occupy larger areas of the lake.

Among the plant communities studied, at least two contrasting groups of phytocoenoses can be distinguished: a group of phytocoenoses associated with mineral substrates, representing early stages of succession (the phytocoenoses of $R$. circinatus, $P$. perfoliatus, $M$. spicatum and $P$. amphibium), and a group of communities restricted to highly hydrated organic substrates, which are characteristic of late stages of lake aging (the phytocoenoses of $M$. verticillatum, $C$. demersum, $S$. aloides and $N$. alba, and in some lakes - patches of $N$. candida and N. pumila).

The present study has demonstrated habitat differentiation of the plant communities dominated by various aquatic species with submerged and floating leaves (Potamion and Nymphaeion). In addition, many aquatic plant communities are good indicators of the habitat conditions (water and substrates) within lakes. Based on the presence of plant communities, it is possible to determine the degree of advancement of the aging process and identify the particular stages of succession in water ecosystems. Our data obtained for the 356 phytocoenoses from 128 lakes will prove a useful basis for developing universal methods of assessing the ecological state of lakes based on macrophyte composition (EU Water Framework Directive). 


\section{References}

Arts G.H.P., 2002. Deterioration of atlantic soft water macrophyte communities by acidification, eutrophication and alkalinisation. Aquat. Bot., 73, 373-393.

Arts G.H.P., Van der Velde G., Roelofs J.G.M. and Van Swaay C.A.M., 1990. Successional changes in the soft-water macrophyte vegetation of (sub)atlantic, sandy lowland regions during this century. Freshwater Biol., 24, 287-294.

Barko J.W. and Smart R.M., 1983. Effect of organic matter additions to sediment on the growth of aquatic plants. $J$. Ecol., 71, 161-175.

Barko J.W. and Smart R.M., 1986. Sediment-related mechanisms of growth limitation in submersed macrophytes. Ecology, 67, 1328-1340.

Barko J.W., Gunnison D. and Carpenter S.R., 1991. Sediment interactions with submersed macrophyte growth and community dynamics. Aquat. Bot., 41, 41-65.

Blindow H., 1992. Decline of charophytes during eutrophication: comparison with angiosperms. Freshwater Biol., 28, 9-14.

Carpenter S.R. and Lodge D.M., 1986. Effects of submerged macrophytes on ecosystem processes. Aquat. Bot., 26, 341-370.

Chambers P.A., Lacoul P. and Murphy K.J., 2008. Global diversity of aquatic macrophytes in freshwater. Hydrobiologia, 595, 9-26.

De Lyon M.J.H. and Roelofs J.G.M., 1986a. Waterplanten in relatie tot waterkwaliteit en bodemgesteldheid. Deel 1 . Laboratorium voor Aquatische Oecologie, Katholieke Universiteit Nijmegen, Nijmegen, $106 \mathrm{p}$.

De Lyon M.J.H. and Roelofs J.G.M., 1986b. Waterplanten in relatie tot waterkwaliteit en bodemgesteldheit. Deel 2. Laboratorium voor Aquatische Oecologie, Katholieke Universiteit Nijmegen, Nijmegen, 126 p.

Del Pozo R., Fernandes-Alez C. and Fernandez-Alez M., 2010. An assessment of macrophyte community metrics in the determination of the ecological condition and total phosphorus concentration of Mediterranen ponds. Aquat. Bot., 92, 55-62.

Doll R., 1991. Die Pflanzengesellschaften der stehenden Gewässer in Mecklemburg-Vorpommern. Teil I.3. Potamogetonetea Tx. Et Prsg. 42. Laichkrautgesellschaften. Feddes Repert., 102, 217-317.

Egerston C.J., Kopaska J.A. and Downing J.A., 2004 . A century of change in macrophyte abundance and composition in response to agricultural eutrophication. Hydrobiologia, 524, 145-156.

European Commission, 2000. Directive 2000/60/EC of the European Parliament and of the Council of 23 October 2000 establishing a framework for Community action in the field of water policy. Official J. Eur. Com., L327, 1-72.

Free G., Bowman J., McGarrigle M., Caroni R., Donnelly K., Tierney D., Trodd W. and Little R., 2009. The identification, characterization and conservation value of isoetid lakes in Ireland. Aquat. Conserv.: Mar. Freshwater Ecosyst., 19, 264 273.

Gaudet J.J. and Muthuri F.M., 1981. Nutrient relationships in shallow water in an African Lake. Lake Naivasha. Oecologia (Berlin), 49, 109-118.

Hach Company, 1992. Hach Water Analysis Handbook, Hach Co., Loveland, Colorado, 831 p.
Heegaard E., Briks H.H., Gibson C.E., Smith S.J. and WolfeMurphy S., 2001. Species-environmental relationships of aquatic macrophytes in Northern Ireland. Aquat. Bot., 70, 175-123.

Hermanowicz W., Dożańska W., Dojlido J. and Koziorowski B., 1999. Fizyczno-chemiczne badanie wody i ścieków, Arkady, Warszawa, $847 \mathrm{p}$.

Hinneri S., 1976. On the ecology and phenotypic plasticity of vascular hydrophytes in a sulphate-rich, acidotrophic freshwater reservoir, SW coast of Finland. Ann. Bot. Fenn., 13, 97-105.

Jackson S.T. and Charles D.F., 1988. Aquatic macrophytes in Adirondack (New York) lakes: pattern of species composition in relation to environment. Can. J. Bot., 66, 1449-1460.

James W.F. and Barko J.W., 1990. Macrophhyte influences on the zonation of sediment accretion and composition in a north-temperature reservoir. Arch. Hydrobiol., 120, 129-142.

Jongman R.H.G., Ter Braak C.J.F. and Van Tongeren O.F.R., 1987. Data Analysis in Communities and Landscape Ecology, Pudoc. Wageningen, The Netherlands. Reissued in 1995 by Cambridge University Press, Cambridge, $x i x+299$ p.

Kadono Y., 1982. Occurrence of aquatic macrophytes in relation to $\mathrm{pH}$, alkalinity, $\mathrm{Ca}^{++}, \mathrm{Cl}^{-}$and conductivity. Japan. J. Ecol., 32, 39-44.

Kłosowski S., 1985. Habitat conditions and bioindicator value of the main communities of aquatic vegetation in north-east Poland. Pol. Arch. Hydrobiol., 32, 7-29.

Kłosowski S., 1990. Litoralvegetation stehender GewässerÖkologie, Dynamik und Bioindikationswert. Pol. Bot. Stud., 1, 149-184.

Kłosowski S., 1992. Temporal and spatial variation of habitat conditions in the zonation of littoral plant communities. Aquat. Bot., 43, 199-208.

Kłosowski S., 2006. The relationships between environmental factors and the submerged Potametea associations in lakes od north-eastern Poland. Hydrobiologia, 560, 15-29.

Kłosowski S. and Jabłońska E., 2009. Aquatic and swamp plant communities as indicators of operties of astatic water bodies in north-eastern Poland. Limnologica, 39, 115-127.

Kłosowski S. and Tomaszewicz H., 1990. Standortverhältnisse des Nupharetum pumili Oberdorfer 1957 in der SuwałkiSeenplatte (Nord-Ostpolen). Arch. Hydrobiol., 117, 365-382.

Kozlowski G. and Eggenberg S., 2005. Vorkommen der Kleinen Teichrose Nuphar pumila und des Hybrids $N . \times$ intermedia in der Schweiz. Bot. Helv., 115, 125-136.

Kunii H., 1991. Aquatic macrophyte composition in relation to environmental factors of irrigation ponds around Lake Shinji, Shimane, Japan. Vegetation, 97, 137-148.

Lacoul P. and Freedman B., 2006. Relationships between aquatic plants and environmental factors along a steep Himalayan altitudinal gradient. Aquat. Bot., 84, 3-16.

Lind C.T. and Cottam G., 1969. The submerged aquatics of University Bay: a study of eutrophication. Am. Mid. Nat., 81, 353-369.

Lorens B., Grądziel T. and Sugier P., 2003. Changes in vegetation of restored water-land ecotone of Lake Bikcze (Polesie Lubelskie Region, Eastern Poland) in the years 1993-1998. Pol. J. Ecol., 51, 175-182.

Lukács B.A., Dévai G. and Tóthmérész B., 2009. Aquatic macrophytes as bioindicators of water chemistry in nutrient rich backwaters along the Upper-Tisza river (in Hungary). Phytocoenologia, 39, 287-293. 
Lumbreras A., Olives A., Quintana J.R., Pardo K. and Molina J.A., 2008. Ecology of aquatic Ranunculus communities under the Mediterranen climate. Aquat. Bot., 90, $59-66$.

Mäemets H., Palmik K., Haldna M., Sudnitsyna D. and Melnik M., 2010. Eutrophication and macrophyte species richness in the large shallow North-European Lake Pepsi. Aquat. Bot., 92, 273-280.

Mäkelä S., Huitu E. and Arvola L., 2004. Spatial patterns in aquatic vegetation composition and environmental covariates along chains of lakes in the Kokemänjoki watershed (S. Finland). Aquat. Bot., 80, 253-269.

Marek S., 1992. Transformation of lakes in mires. Acta Soc. Bot. Pol., 61, 103-113.

McElarney Y.R. and Rippey B., 2009. A comparison of lake classifications based on aquatic macrophytes and physicaland chemical water body descriptors. Hydrobiologia, 625, 195-206.

Melzer A., 1999. Aquatic macrophytes as tools for lake management. Hydrobiologia, 395/396, 181-190.

Misra R.D., 1938. Edaphic factors in the distribution of aquatic plants in the English lakes. J. Ecol., 26, 411-451.

Misztal M., Smal H., Ligęza S. and Dymińska-Wydra P., 2003. Influence of land-lake ecotone on minera land organic compounds in groundwater and lake water. Pol. J. Ecol., 51, 129-136.

Moyle J.B., 1945. Some chemical factors influencing the distribution of aquatic plants in Minnesota. Am. Midl. Nat., 34, 400-420.

Nurminen L., 2003. Macrophyte species composition reflecting water quality changes in adjacent water bidues of lake Hiiddenvesi, SW Finland. Ann. Bot. Fenn., 40, 199-208.

Nõges P. and Kisand A., 1999. Horizontal distribution of sediment phosphorus in shallow eutrophic Lake Võrtsjärv (Estonia). Hydrobiologia, 408/409, 167-174.

Papastergiadou E. and Babalonas D., 1993a. The relationships between hydrochemical environmental factors and the aquatic macrophytic vegetation in stagnant and slow flowing waters. I. Water quality and distriburion of aquatic associations. Arch. Hydrobiol., Suppl., 90, 475-491.

Papastergiadou E. and Babalonas D., 1993b. The relationships between hydrochemical environmental factors and the aquatic macrophytic vegetation in stagnant and slow flowing waters. II. Evaluation of plant associations indicative value. Arch. Hydrobiol., Suppl., 90, 493-506.

Penning W.E., Mjelde M., Dudley B., Hellsten S., Hanganu J., Kolada A., Van den Berg M., Mäemets H., Poikane S., Philips G., Willby N. and Ecke F., 2008a. Classifying aquatic macrophytes as indicators of eutrophication in European lakes. Aquat. Ecol., 42, 237-251.

Penning W.E., Dudley B., Mjelde M., Hellsten S., Hanganu J., Kolada A., Van den Berg M., Mäemets H., Poikane S., Philips G., Willby N. and Ecke F., 2008b. Using aquatic macrophyte community indices to define the ecological status of European lakes. Aquat. Ecol., 42, 253-264.

Pieczyńska E., 1972. Ecology of the eulittoral zone of lakes. Ekol. Pol., 20, 637-732.

Pietsch W., 1972. Ausgewälte beispiele für Indikatoreigenschaften höherer Wasserpflanzen. Arch Naturschutz $u$. Landschaftsforsch., 12, 121-151.

Pietsch W., 1982. Makrophytische Indikatoren für ökochemische Beschaffenheit der Gewässer. In: Breitig G. and Tümpling W. (eds.), Ausgewählte Methoden der Wasseruntersuchung, Bd 2, Gustav Fischer Verlag, Jena, 67-88.

Pip E., 1988. Niche congruency of aquatic macrophytes in central North America with respect to 5 water chemistry parameters. Hydrobiologia, 162, 173-182.

Planter M., 1973. Physical and chemical conditions in the helophytes zone of the lake littoral. Pol. Arch. Hydrobiol., 20, 1-7.

Rejewski M., 1981. Roślinność jezior rejonu Laski w Borach Tucholskich, Uniwersytet Mikołaja Kopernika, Toruń, $178 \mathrm{p}$.

Roelofs J.G.M., 1983. Impact of acidification and eutrophication on macrophyte communities in soft waters in the Netherlands. Aquat. Bot., 17, 139-155.

Roweck H., 1988. Ökologische Untersuchungen an Teichrosen. Arch. Hydrobiol., Suppl., 81, 103-358.

Sand-Jensen K., Tenna R., Vesterrgaard O. and Larsen-Soren E., 2000. Macrophyte decline in Danish lakes and streams over the past 1000 years. J. Ecol., 88, 1030-1040.

Sass L., Bozek M.A., Hauxwell J.A., Wagner K. and Knight S., 2010. Response of aquatic macrophytes to human land use perturbation in the watersheds of Wisconsin lakes, U.S.A. Aquat. Bot., 93, 1-8.

Schamburg J., Schranz C., Hofmann G., Stelzer D. and Schneider S., 2004. Macrophytes and phytobenthos as indicators of ecological status in German lakes - a contribution to the implementation of the Water Framework Directive. Limnologica, 34, 302-314.

Schmieder K. and Lehmann A., 2004. A spatio-temporal framework for efficient inventories of natural resources: A case study with submersed macrophytes. J. Veg. Sci., 15, 807-816.

Schneider S., 2007. Macrophyte trophic indicator values from a European perspective. Limnologica, 37, 281-289.

Smits A.J.M., De Lyon M.J.H., Van der Velde G., Steentjes P.L.M. and Roelofs J.G.M., 1988. Distribution of three nymphaeid macrophytes (Nymphaea alba L., Nuphar lutea (L.) Sm. and Nymphoides peltata (Gmel.) O. Kuntze) in relation to alkalinity and uptake of inorganic carbon. Aquat. Bot., 32, 45-62.

Spence D.H.N., 1967. Factors controlling the distribution of freshwater macrophytes with particular reference to the lochs of Scotland. J. Ecol., 55, 147-170.

Spence D.H.N., 1982. The zonation of plants in freshwater lakes. Adv. Ecol. Res., 12, 37-125.

Szańkowski M. and Kłosowski S., 2001. Habitat conditions of the phytocoenoses dominated by Luronium natans (L.) Rafin in Poland. Hydrobiologia, 455, 213-222.

Szańkowski M. and Kłosowski S., 2006. Habitat variability of the Littorelletea uniflorae plant communities in Polish Lobelia lakes. Hydrobiologia, 570, 117-126.

Ter Braak C.J.F., 1986. Canonical correspondence analysis: a new eigenvector technique for nultivariate direct gradient analysis. Ecology, 67, 1167-1179.

Ter Braak C.J.F. and Šmilauer P., 1998. CANOCO Reference Manual and User's Guide to Canoco for Windows. Software for Canonical Community Ordination (version 4), Centre for Biometry, Wageningen \& Ithaca, Microcomputer Power, New York.

Toivonen H. and Huttunen P., 1995. Aquatic macrophytes and ecological gradients in 57 small lakes in southern Finland. Aquat. Bot., 51, 197-221. 
Tomaszewicz H., 1979. Roślinność wodna I szuwarowa Polski (klasy Lemnetea, Charetea, Potamogetonetea, Phragmitetea) według stanu zbadania na rok 1975. Rozpr. Uniw. Warsz., 160, 1-325.

Tóth L.G., Poikane S., Penning E.W., Free G., Mäemets H., Kolada A. and Hanganu J., 2008. First steps in the CentralBaltic intercalibration exercise on lake macrophytes: where do we start? Aquat. Ecol., 42, 265-275.

Úlehlová B. and Pribil S., 1978. Water chemistry in the fishpond littorals. In: Dykyjová D. and Květ J. (eds.), Pond Littoral Ecosystems. Structure and Functioning, Ecological Studies, 28, Springer, Berlin, 126-140.

Van der Velde G., Custers C.P.C. and De Lyon M.J.H., 1986. The distribution of four nymphaeid species in the Netherlands in relation to selected abiotic factors. In: Proceedings EWRS/AAB, 7th Symposium on Aquatic Weeds, 363-368.

Van Groenendael J.M., Roepers R.G., Woltjer I. and Zweers H.R., 1996. Vegetation succession in lakes of West Connemara, Ireland: comparing predicted and actual changes. J. Veg. Sci., 7, 211-218.
Van Katwijk M.M. and Roelofs J.G.M., 1988. Vegetaties van waterplanten in relatie tot het milieu, Laboratorium voor Aquatische Oecologie, Katholieke Universiteit Nijmegen, Nijmegen, 133 p.

Vestergaard O. and Sand-Jensen K., 2000. Alkalinity and trophic state regulate aquatic plant distribution in Danish lakes. Aquat. Bot., 67, 85-107.

Wiegleb G., 1978. Untersuchungen über den Zusammenhang zwischen hydrochemischen Umveltfaktoren und Makrophytenvegetation in stehenden Gewässern. Arch. Hydrobiol., 83, 443-484.

Wilcox D.A. and Simonin H.A., 1987. A chronosequence of aquatic macrophyte communities in dune ponds. Aquat. Bot., $28,227-242$.

Willby N.L., Abernethy V.J. and Demars B.O.L., 2000. Attribute-based classification of European hydrophytes and its relationship to habitat utilization. Freshwater Biol., 43, 43-74.

Zar J.A., 1984. Biostatistical Analysis, Prentice-Hall, Englewood Cliffs, New Jersey, 718 p. 